International Journal of Current Advanced Research

ISSN: O: 2319-6475, ISSN: P: 2319 - 6505, Impact Factor: SJIF: 5.995

Available Online at www.journalijcar.org

Volume 6; Issue 3; March 2017; Page No. 2736-2737

DOI: http://dx.doi.org/10.24327/ijcar.2017.2737.0092

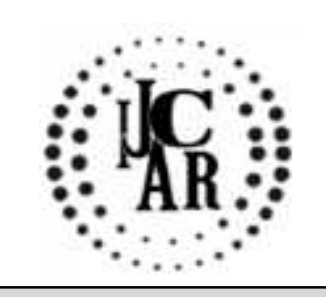

Research Article

\title{
IN VITRO ANTIOXIDANT ACTIVITY OF CORIANDRUMSATIVUM EXTRACT
}

\section{Godlin Jeneta J and Geetha R.V}

Saveetha Dental College and Hospital 162, P.H Road, Chennai, Tamilnadu 600077

\begin{tabular}{l}
\hline A R T I C L E I N F O \\
Article History: \\
Received $15^{\text {th }}$ December, 2016 \\
Received in revised form $19^{\text {th } J a n u a r y, ~} 2017$ \\
Accepted $20^{\text {th }}$ February, 2017 \\
Published online $28^{\text {th }}$ March, 2017
\end{tabular}

Key words:

Coriander, Coriandrumsativum Extract

\begin{abstract}
A B S T R A C T
Aim: And Objective: To asses the antioxidant activity of Coriandrumsativum extract.

Background: Coriander is an annual herb. All parts of the plant are edible and are non toxic to humans Leaves are particularly rich in vitamin A, vitamin C and vitamin $\mathrm{K}$. Seeds generally have lower contents of vitamins, they do provide significant amounts of dietary fibre, calcium, selenium, iron, magnesium and manganese. The plant posses a broad spectrum of anti bacterial, anti fungal, anti microbial, anti spoilage and anti oxidant activity.
\end{abstract}

Method: Antioxidant activity of Coriandrumsativum was screened using DPPH and Hydrogen peroxide scavenging assays

Result: At a concentration of $100 \mathrm{ug} / \mathrm{ml}$ both ethanolic extract and standard Ascorbic acid showed $86.89 \%$ and $98.20 \%$ antioxidant activity by DPPH radicals scavenging assay

Copyright $@ 2017$ Godlin Jeneta J and Geetha R.V. This is an open access article distributed under the Creative Commons Attribution License, which permits unrestricted use, distribution, and reproduction in any medium, provided the original work is properly cited.

\section{INTRODUCTION}

Free radicals or reactive oxygen species (ROS) exert oxidative stress towards the cells of the body by various mechanisms and cause damage to cellular proteins, nucleic acids, membrane lipids, and eventually cell death. All cells in the body has an enzymatic and non enzymatic defence system.[1] Antioxidants prevent or delay oxidative damage of lipids, proteins and nucleic acids by reactive oxygen species.[2] However synthetic antioxidants are supplemented occasionally to reduce the oxidative damage. These are not well accepted due to its side effects. [3] Natural sources are alternatives which doesn't have any side effects and has antioxidant effect. Fruits are rich in antioxidants that help in lowering incidence of degenerative diseases such as cancer, arthritis, arteriosclerosis, heart disease, inflammation, brain dysfunction and acceleration of the ageing process.[2] Coriandrumsativum is a culinary and medicinal herb of the Apiaceae family commonly known as coriander. The roots and leaves of $\mathrm{C}$. sativum are rich with aromatic flavour and are used in Asian cooking. The plant parts are used to alleviate spasms, gastric complaints, bronchitis, gout and giddiness. [4] It has medicinal properties, including antidiabetic, antioxidant, hypocholesterolemic, antihelmintic, antibac- terial, hepatoprotective, anticancer and anxiolytic activities. [5]. The plant is grown widely all over the world for seed, as a spice, or for essential oil production. [6]

\section{*Corresponding author: Godlin Jeneta J}

Saveetha Dental College and Hospital 162, P.H Road, Chennai, Tamilnadu 600077
Antioxidant ac- tivities can be affected by location and growth conditions of the plant. [5] Polyphenolic compounds are present in C. sativum, and are known to be excellent antioxidants. They have the capacity to reduce free-radical formation by scavenging free radicals and protecting antioxidant defenses. [6] Researches says that caffeic acid, protocatechinic acid, and glycitin were present in coriander aerial parts. They are principal components responsible for the antioxidant activity of the aqueous coriander extract.[7]

\section{MATERIALS AND METHODS}

Measurement of the Antioxidant Activity DPPH Radical scavenging test:

The free radical scavenging activity of the Coriandrumsativum extract was determined by using 2,2 Diphenyl-1-picrylhydrazyl radical (DPPH) using UVSpectrometry at $517 \mathrm{~nm}$. The DPPH solution was prepared in 95\% methanol. The extract was mixed with $95 \%$ methanol to prepare the stock solution $(10 \mathrm{mg} / 100 \mathrm{ml})$. From the stock solution $2 \mathrm{ml}, \mathrm{ml}, 6 \mathrm{ml}, 8 \mathrm{ml}$ and $10 \mathrm{ml}$ were taken in five test tubes and diluted with same solvent to get a final concentration of $20 \mathrm{~g} / \mathrm{ml}, 40 \mathrm{~g} / \mathrm{ml}, 60 \mathrm{~g} / \mathrm{ml}, 80 \mathrm{~g} / \mathrm{ml}$ and $100 \mathrm{~g} / \mathrm{ml}$ respectively. $2 \mathrm{ml}$ of freshly prepared DPPH solution $(0.004 \% \mathrm{w} / \mathrm{v})$ was added in each of these test tubes containing $1 \mathrm{ml}$ of the test extract and after 30min, the absorbance was taken at $517 \mathrm{~nm}$ using spectrophotometer. Ascorbic acid was used as standard.

The percentage of DPPH radical scavenging is as follows: $\%$ of DPPH radical scavenging = (Absorbance of controlAbsorbance of test Sample) x 100/ (Absorbance of control) 


\section{Hydrogen Peroxide Scavenging Activity}

The ability of plant extracts to scavenge hydrogen peroxide is determined by taking $0.5 \mathrm{ml}$ of hydrogen peroxide, $1 \mathrm{ml}$ of Sodium phosphate buffer $\mathrm{pH} 7.4,0.01 \mathrm{~m}$, w/v (mixing $30 \mathrm{ml}$ of solution A-156mg of sodium dihydrogen phosphate was dissolved in $100 \mathrm{ml}$ of distilled water; with $70 \mathrm{ml}$ of solution B-178mg of disodium hydrogen phosphate was dissolved in $100 \mathrm{ml}$ of distilled water) and $0.4 \mathrm{ml}$ water. $0.1 \mathrm{ml}$ of the sample was added to initiate the reaction. $2 \mathrm{ml}$ dichromate acetic acid reagent was added after 15, 30, 45 and $60 \mathrm{sec}$ to arrest reaction to the control tubes. The tubes were then heated for 10 minutes allowed to cool and the green colour developed was read at $240 \mathrm{~nm}$ using spectrophotometer.

The percentage of hydrogen peroxide scavenging is calculated as follows.

$\%$ Scavenged $(\mathrm{H} 2 \mathrm{O} 2)=(\mathrm{A} 0-\mathrm{A} 1 / \mathrm{A} 0) \mathrm{X} 100$ Where; $\mathrm{A} 0$ is the absorbance of control and A1 is the absorbance of test

\section{RESULTS AND DISCUSSION}

The following result is obtained from DPPH scavenging test:

\begin{tabular}{|c|c|c|}
\hline senxorictextict llai & 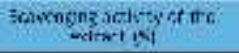 & 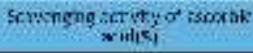 \\
\hline$x$ & 15.45 & All: \\
\hline$\Leftrightarrow$ & s. & $=b$. \\
\hline$m$ & $\infty 15$ & $\operatorname{mas}$ \\
\hline$w:$ & 4.i. & ste \\
\hline 10: & 8..50 & $\sec$ \\
\hline
\end{tabular}

DPPH radicals scavenging activity of Coriandrumsativum extract

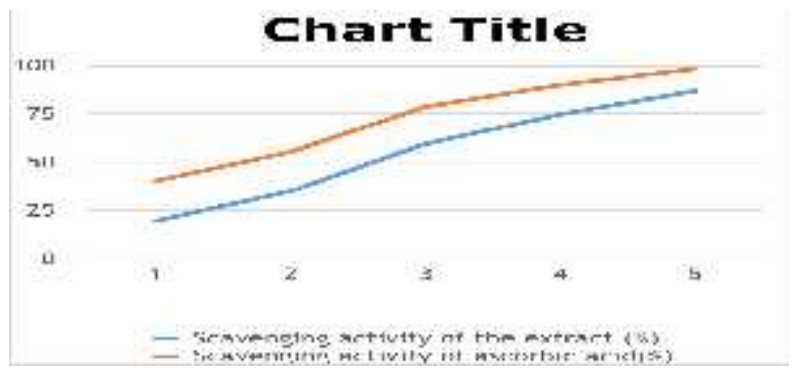

The following result is obtained from Hydrogen peroxide scavenging test

\begin{tabular}{|c|c|c|}
\hline Geditets.7bla & \multicolumn{2}{|c|}{ 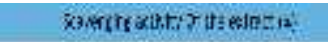 } \\
\hline & x & s 11 \\
\hline & 4 & \& \\
\hline & $\alpha$ & $\omega: 2$ \\
\hline & * & $\pi+13$ \\
\hline & s & 812 \\
\hline
\end{tabular}

The DPPH radical scavenging activity of ascorbic acid and ethanolic extracts of Coriandrumsativum increases in a dosedependent manner. At a concentration of $100 \mathrm{ug} / \mathrm{ml}$ both ethanolic extract and standard Ascorbic acid showed $86.89 \%$ and $98.20 \%$ antioxidant activity by DPPH radicals scavenging assay. Though the exact composition of the phenolic compounds present in the ethanolic extract has yet to be fully elucidated, it could exhibit good anti-radical activity.
The ethanolic extract of Coriandrumsativum was capable of scavenging $\mathrm{H} 2 \mathrm{O} 2$ in a dose dependent manner.

The DPPH radical scavenging test and hydrogen peroxide scavenging test shows that Coriandrumsativum has high anti oxidant activity. Their activity is important because they help to protect the human body against damages induced by reactive free radicals generated in atherosclerosis, ischemic heart disease, cancer, Alzheimer's disease, Parkinson's disease, and even in aging process. [8] Antioxidant-based formulations can be used for prevention and treatment of many illnesses such as atherosclerosis, stroke, diabetes.[9] Thus, further researchs should be done to emphasise Coriandrumsativum activity to be employed in new therapeutic drugs.

\section{CONCLUSION}

The ethanolic extract of exhibited different levels of antioxidant activity in both the models utilized for the free radical scavenging activity. Further investigation of the compounds responsible for the antioxidant activity, its isolation and in vivo studies are needed.

\section{References}

1. N.Madhusudan et al: Invitro Antioxidant And Free Redical Scavenging Activity Of Aqueous And Ethenolic Flower Extract Of NyampheaAlba, JulySeptember 2011 | Vol. 3 | Issue 3 | ISSN 0975-9344.

2. The Antioxidant Effect of Certain Fruits: - A Review ShehanazArshiya/J. Pharm. Sci. \& Res.Vol.5(12), 2013, 265- 268

3. Anagnostopoulou MA, Kefalas P, Papageorgiou VP, Assimepoulou AN, Boskou, D, Radical scavenging activity of various extracts and fractions of sweet orangepeel (Citrus sinensis), Food Chem, 94, 2006, 1925.

4. Sreelatha S, Padma P, Umadevi M: Protective effects of Coriandrumsativum extracts on carbon tetrachlorideinduced hepatotoxicity in rats. Food ChemToxicol 2009, 47:702-708.

5. Antioxidant activity of Coriandrumsativum and protection against DNA damage and cancer cell migration Esther LH Tang, Jayakumar Rajarajeswaran, Shin YeeFung and MS Kanthimathi. http://www.biomedcentral.com/1472-6882/13/347

6. Phytochemistry, pharmacology and medicinal properties of Coriandrumsativum L. JinousAsgarpanah and NastaranKazemivash, DOI: 10.5897/AJPP12.901

7. Melo EA, Filho JM, Guerra NB (2005). Characterization of antioxidant compounds in aqueous coriander extract (Coriandrumsativum L.). Food Sci. Technol. 38(1):15-19.

8. Aruoma OI (2003). Methodological considerations for characterizing potential antioxidant actions of bioactive components in plant foods. Mutat. Res. 523-524:9-20.

9. Phytochemical Analysis and In vitro Antioxidant Activity of Jojoba Oil, SuhasManoharan et al $/ J$. Pharm. Sci. \& Res. Vol. 8(6), 2016, 512-516. 